\title{
Cerrahi Alanlarda Çalışan Hemşirelerde Örgütsel Sinizmin Bakım Davranışları ve Çalışma Yaşam Kalitesine Etkisi
}

\section{The Effect of Organizational Cynicism on Care Behaviors and Professional Quality of Life on Nurses Working in Surgical Fields}

\author{
Senan Mutlu ${ }^{1}$, Emel Y1lmaz ${ }^{1 *}$ \\ ${ }^{1}$ Manisa Celal Bayar Üniversitesi Sağlık Bilimleri Fakültesi Hemşirelik Bölümü, Cerrahi Hastalıkları, Manisa, \\ Türkiye. \\ e-mail: senantunali0726@gmail.com, emelyilmazcbu@gmail.com \\ ORCID: 0000-0002-5127-6651 \\ ORCID: 0000-0002-0409-5209 \\ *Sorumlu yazar/ Corresponding Author: Emel Yilmaz \\ Gönderim Tarihi / Received: 15.03.2021 \\ Kabul Tarihi / Accepted: 05.04.2021 \\ DOI: $10.34087 /$ cbusbed. 896919
}

\section{Öz}

Giriş ve Amaç: Bu araştırma cerrahi alanlarda çalışan hemşirelerde örgütsel sinizmin bakım davranışları ve çalışma yaşam kalitesine etkisini belirlemek amacıyla yapıldı.

Gereç ve Yöntemler: Tanımlayıcı ve kesitsel türdeki bu araştırmaya Türkiye'nin Batı bölgesinde bulunan bir üniversite hastanesinin cerrahi kliniklerinde çalışan 60 hemşire dahil edildi. Araştırma öncesinde etik kurul onayı alındı. Veriler yüz yüze görüşme yöntemi ile kişisel bilgi formu, Örgütsel Sinizm Ölçeği (ÖSÖ), Çalışanlar için Yaşam Kalitesi Ölçeği (ÇYKÖ) ve Bakım Davranışları Ölçeği -24 (BDÖ-24) kullanılarak toplandı. Verilerin değerlendirilmesinde tanımlayıcı istatistikler, Mann Whitney U testi ve Spearman korelasyon analizi kullanıldı.

Bulgular: Araştırmaya katılan hemşirelerin yaş ortalaması 28.58 \pm 6.77 yıldır. Hemşirelerin ÖSÖ toplam puan ortalamas1 34.55 \pm 6.71 , ÇYKÖ alt boyut puan ortalamaları; mesleki tatmin:27.62 \pm 6.62 , tükenmişlik $7.57 \pm 2.73$ ve eşduyum yorgunluğu $17.10 \pm 7.35$ ve BDÖ-24 toplam puan ortalaması ise $5.20 \pm 0.45$ olarak saptand1. Örgütsel Sinizm Ölçeği toplam puanı ile ÇYKÖ alt boyutlarından mesleki tatmin arasında negatif yönlü orta $\left(\mathrm{r}_{\mathrm{s}}=-0.456, \mathrm{p}<0.001\right)$,

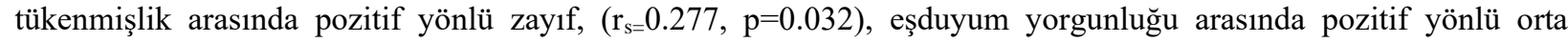
$\left(\mathrm{r}_{\mathrm{s}=} 0.372, \mathrm{p}=0.003\right)$ düzey ilişki belirlendi.

Sonuç: Araştırmada, örgütsel sinizme maruz kalan hemşirelerin meslekle ilgili memnuniyet ve tatmin düzeylerinin olumsuz olarak etkilendiği, tükenmişlik ve eşduyum yorgunluklarının da arttığı saptandı. Ayrıca meslekte yeni ve daha genç olan hemşirelerin BDÖ-24 puanının daha yüksek olduğu bulundu.

Anahtar kelimeler: Bakım davranışları, Çalışanlar için yaşam kalitesi, Hemşire, Sinizm.

\section{Abstract}

Objective: The purpose of this research was to investigate the effect of organizational cynicism on care behaviors and working life quality of nurses working in surgical fields.

Materials and Methods: This descriptive and cross sectional study was conducted at university hospital in western of Turkey. The study sample consists of the 60 nurses working at surgical clinics. Ethics approval was obtained before study. Data were collected using face-to-face interview method, personal information form, Organizational Cynicism Scale (OCS), Professional Quality of Life Scale (ProQOL), and Caring Behaviors Inventory-24 (CBI-24). Descriptive statistics, Mann Whitney U test and Spearman correlation analysis were used to analyze the data.

Results: The mean age of the nurses participating in the study was $28.58 \pm 6.77$. Nurses' total OCS mean score was $34.55 \pm 6.71$, the mean scores for the sub-dimension of the ProQOL; compassion satisfaction was 27.62 \pm 6.62 , burnout was 7.57 \pm 2.73 , compassion fatigue was $17.10 \pm 7.35$, and the CBI-24 total score mean was $5.20 \pm 0.45$. The negative moderate correlation between the total score of the OCS and the compassion satisfaction from the sub-dimensions of ProQOL $\left(\mathrm{r}_{\mathrm{s}}=-0.456, \mathrm{p}<0.001\right)$, positive weak correlation between burnout $\left(\mathrm{r}_{\mathrm{s}}=0.277, \mathrm{p}=0.032\right)$, the positive moderate correlation between compassion fatigue $\left(\mathrm{r}_{\mathrm{s}}=0.372, \mathrm{p}=0.003\right)$ was detected. 
Conclusion: In the study, it was found professional satisfaction of nurses exposed to organizational cynicism were negatively affected, their burnout and compassion fatigue increased. In addition, the new and younger nurses in the profession CBI-24 scores were found to be higher.

Keywords: Cynicism, Care behaviors, Nurse, Professional quality of life.

\section{Giriş}

Sağlık çalışanları, toplumun sağlığını koruyup iyileştirmede önemli bir yere sahiptirler. Bireylerin sağlığında çok büyük rolü olan sağlık çalışanlarının kendilerini güvende hissettikleri bir ortamda hizmet vermeleri önemlidir. Günümüzde sağlık çalışanlarının güvenli ortamda çalışmasını riske atan, kimyasal, biyolojik, psiko-sosyal ve fiziksel birçok tehlike bulunmaktadır. Psiko-sosyal boyut olan iş yeri zorbalığı da sağlık çalışanları için iş yerinde güvenliklerini tehdit eden önemli bir unsurdur. Hastanelerde bu zorbalıkla karşılaşmış, huzursuz, performansı düşük ve mutsuz bir sağlık çalışanı istemeyerek de olsa verilen sağlık hizmeti açısından önemli bir tehlike oluşturmaktadır[1].

Bireyler bir örgütte veya kurumda çalışmaya başladıklarında amaç ve beklentilerini gerçekleştirmek isterler [2]. Örgütte yapılan hatalı uygulamalar ve örgüt kültürü nedeniyle oluşan iş yeri zorbalığı, krizler ve hasarlar çalışanlarda örgütlerine karşı ciddi derecede tedirginlik, güvensizlik, monotonluk, yılma, yabancılaşma, endişe gibi olumsuz davranış, tutum ve düşüncelerin gelişmesine neden olmaktadır. Sinizm de bunlar arasında yer almaktadır [3]. Sinizm, deneyimlenen tecrübelerle beslenen, olumsuz hisleri belirten bir kelimedir ve yitirilmiş inançlar olarak da belirtilmektedir [4,5]. Bu kavramda inanmama ve şüphecilik esastır [6]. Sinizmin görüldüğü bireyler çalıştığ kuruma ve iş arkadaşlarına olumlu olmayan düşünceler hissetmektedir. İçten içe büyütülmüş bu olumsuz düşüncelerin hem sağlık kurumuna hem de çalışanlara olumsuz şekilde yansıyacağ [1].

Örgütsel sinizmin üç boyutu vardır. $\mathrm{Bu}$ boyutlar bilişsel, duyuşsal ve davranışsal olarak ayrılmaktadır [7]. Bilişsel boyutta sinik bireyler samimiyet, dürüstlük, adalet gibi kavramların bireylerin çıkarları için kullanıldığına, vicdani olmayan tutumların standart olduğuna, genellikle yapılan davranışların altında gizli sebeplerin olduğuna [8], örgütlerinde de ahlaksızca davranışların norm haline geldiğine ve bu ilkelerin genellikle ilkesizliğe kurban edildiğine inanırlar [9]. Duyuşsal boyutta ise örgüt içinde sinik davranış gösteren bireylerin, bu düşüncelerini yalnızca inanç olarak değil, örgüte ilişkin duygu olarak da göstermesidir [10]. Duyuşsal boyutta öfke, sıkıntı, saygısızlık ve utanç gibi etkili duygusal tepkiler yer almaktadır. Örgütsel sinizmin davranışsal boyutunda da çalışan bireyler organizasyona karşı kötüleyici, şikâyetçi, alaycı, küçümseyici eleştiriler sergilerler [11, 12].

Literatürde, örgütte sinizme sebep olan değişik etmenlerin olduğu belirtilmektedir. Aşırı stres, yetersiz sosyal destek, örgütsel ve kişisel beklentilerin karşılanmaması, artan örgütsel karmaşıklık, yetersiz terfi, iletişimsizlik, amaç çatışması, işten çıkarma, karar almada yetkili olamama sinizm nedenleri arasındadır [13]. Özler ve Atalay'ın 2011 yılında yaptıkları bir çalışmada da örgütsel sinizmin hastane çalışanlarında tükenmeye neden olduğu belirlenmiştir [14]. Ayrıca Gül ve Ağıröz mobbing yapılan hemşirelerin sinik davranış eğilimlerini değerlendirdikleri çalışmada mobbing ve duyuşsal sinizm arasında anlamlı bir ilişki saptamıştır [3].

Sağlık kurumlarının çalışma koşulları iş yaşam kalitesinin istenilen ve beklenen seviyede olduğu kurumlar arasında değildir ve bu kurumlarda kaliteli yaşam şartlarının sağlanmasının daha güç olduğu belirtilmektedir. Sağlık hizmetleri karmaşık, bireye özgü ve değişkendir. Özensizlik, dikkatsizlik, ve ihmalkar hataların bedeli bu alanda daha ağır olmakla birlikte, çoğu zaman insan hayatı ile ödenmektedir [15]. Hemşirelik çalışma ortamından dolayı yoğun iş stresiyle beraber fazla iş yüküne sahiptir. Çalışma ortamındaki bazı faktörler (hasta bireylerle çalışmaya ilişkin yaşanan duygusal stres, hastalar ve yakınlarına ilişkin sorunlar, terminal dönemdeki hastalara bakım verme, çalışma saatlerinin fazlalığ 1 ve nöbet sistemi, yöneticilerle yaşanan çatışmalar gibi) hemşirelerin duyarsızlaşmalarına, tükenmelerine ve hatta mesleklerini bırakmalarına neden olabilmektedir $[16$, 17]. Hemşirelerin olumsuz şartlarda çalışması da bakım davranışlarını kötü yönde etkilemekle beraber, iş yaşam kalitelerinde düşmeye ve sinik davranışlar sergilemelerine yol açmaktadır.

Literatürde hemşirelerde sinizm, bakım davranışları ve iş yaşam kalitelerinin birlikte değerlendirildiği çalışmaya rastlanmamıştır. Bu durum dikkate alınarak çalışma cerrahi alanlarda çalışan hemşirelerde örgütsel sinizmin bakım davranışları ve çalışma yaşam kalitesine etkisinin belirlenmesi amaciyla yapıldı. Araştırma sonuçlarının literatüre katkı sağlayabileceği ve bu konudaki eksikleri giderebileceği düşünülmektedir.

\section{Materyal ve Metot}

\subsection{Araștırmanın Tipi}

Tanımlayıcı ve kesitsel türde bir araştırmadır.

\subsection{Araştımanın Yeri ve Zamanı}

Araştırma 01.06.2019-01.09.2019 tarihleri arasında Türkiye'nin batı bölgesindeki bir üniversite hastanesinde yapıld1.

\subsection{Araştırmanı Evreni ve Örneklemi}

Araştırmaya Türkiye'nin batı bölgesindeki bir üniversite hastanesinin cerrahi servislerinde çalışan hemşireler dahil edildi. Araştırmada örneklem seçimine gidilmeden evren örneklem olarak kabul edildi. Ancak bu süreçte rapor, doğum izni gibi nedenlerden dolay1 39 
hemşireye ulaşılamadı ve çalışma 60 hemşire ile tamamland1 (Katılım oranı: \%75).

Araştırmaya iki aydan fazla süredir bulunduğu klinikte çalışan, işbirliği ve iletişime açık, araştırmaya katılmaya gönüllü olan hemşireler dahil edildi. İki aydan daha kısa süredir bulunduğu klinikte çalışan ve araștırmaya katılmayı kabul etmeyen hemşireler araştırma kapsamına alınmadı.

\subsection{Veri Toplama Araçları}

Araştırmanın verileri yüz yüze görüşme tekniği kullanılarak kişisel bilgi formu, Örgütesl Sinizm Ölçeği (ÖSÖ), Çalışanlar için Yaşam Kalitesi Ölçeği (ÇYKÖ) ve Bakım Davranışları Ölçeği-24 (BDÖ-24) ile topland.

- Kişisel Bilgi Formu: Hemşirelerin sosyo-demografik özellikleri ve çalıştığı birimi ilgilendiren bilgileri kapsayan sorular bulunmaktadır. Bunlar; hemşirelerin yaşı, cinsiyeti, eğitim durumu, gelir düzeyi, medeni durumu, haftalık çalışma saati ve yaptığı işten memnuniyetini belirlemeye yönelik sorulardir.

- Örgütesl Sinizm Ölçeği (ÖSÖ): Bu ölçek Brandes tarafından 1997 yılında geliştirilmiştir. Kalağan Türkçe'ye uyarlamasını 2009 yılında yapmıştır. Toplam 13 madde ve 3 alt boyut (bilişsel, duyuşsal ve davranışsal) içermektedir ve beşli Likert tipindedir. Ölçekten en yüksek 65 ve en düşük 13 puan alınmaktadır. Yüksek puanlar araştırmaya katılanların daha fazla sinik davranış gösterdiğini belirtmektedir [18, 19].

- Çalışanlar için Yaşam Kalitesi Ölçeği (ÇYKÖ): Otuz madde ve üç alt boyuttan oluşmaktadır. Mesleki tatmin ilk boyuttur ve 3, 6, 12, 16, 18, 20, 22, 24, 27, 30 maddeleri içermektedir. $\mathrm{Bu}$ boyuttan alınan yüksek puanlar memnuniyet ve tatmin düzeyini göstermektedir. Tükenmişlik ikinci alt boyuttur ve 1 , $4,8,10,15,17,19,21,26,29$. nolu maddeler bu boyutu ölçmektedir. Yüksek puanlar tükenmişlik düzeyinin yüksek olduğunu belirtmektedir. Eşduyum yorgunluğu üçüncü alt boyuttur 2, 5, 7, 9, 11, 13, 14, $23,25,28$. maddeler yer almaktadır. Bu boyuttan yüksek puan alınması durumunda çalışanların yardım alması önerilir. Ölçeğin 1, 4, 15, 17 ve 29. maddeleri ters çevrilerek hesaplama yapılır. Ölçek maddeleri 0: hiçbir zaman ile 5: çok sık arasında altı basamakta değerlendirilmektedir. Ölçeğin her bir alt boyutundan 0-50, toplamından 0-150 arası puan alınabilmektedir [20].

- Bakım Davranışları Ölçeği-24 (BDÖ-24): Wu ve arkadaşları (2006) tarafından hemşirelik bakım sürecini değerlendirmek amaciyla geliştirlmiştir [21]. Cerrahi girişim öncesi ve sonrası hastaya uygulanan hemşirelik bakımını da içermektedir. Ölçeğin Türkçe geçerlik ve güvenilirliğini Kurşun ve Kanan yapmıştır [22]. Ölçek, güvence (8 madde), bilgi beceri (5 madde), saygilı olma (6 madde) ve bağlılık (5 madde) olarak dört alt boyut ve 24 maddeden oluşmaktadır. Ölçek 6'lı Likert tipi (1: asla, 2:hemen hemen asla, 3: bazen, 4: genellikle, 5: çoğu zaman, 6: her zaman) olarak puanlanmaktadır. Ölçek puanlamasında 24 maddenin toplam puanı 24'e bölünür ve 1-6 arasında ölçek puanı elde edilir. Alt boyut puanları için ise her bir alt boyutta yer alan maddelerin toplam puanı o boyuttaki madde sayısına bölünür. 1-6 arasında bir puan bulunur. Yüksek puanlar hemşirelik bakım kalitesine bağlı daha olumlu algıyı göstermektedir [21, 22].

Araştırma verileri hemşirelerle yüz yüze görüşme yöntemi ile hemşire odasında yaklaşık 15-20 dakikada toplandı. Araştırma öncesinde Tıp Fakültesi Sağlık Bilimleri Etik Kurulu'ndan ve araştırmanın yapıldığ hastaneden izin alındı. Aynı zamanda araştırmaya katılan hemşirelere araştırmanın amacı anlatılarak yazılı ve sözel onamları alındı.

Veriler SPSS 15.0 programında analiz edildi. Verilerin normal dağılıma uygunluğu Shapiro Wilk testi ile değerlendirildi. Verilerin analizinde tanımlayıcı istatistikler, Mann Whitney $U$ testi ve Spearman korelasyon analizi kullanıldı. $\mathrm{p}<0.05$ istatistiksel olarak anlamlı kabul edildi.

\section{Bulgular ve Tartışma}

\subsection{Bulgular}

Araştırmaya katılan hemşirelerin yaş ortalaması 28.58 \pm 6.77 (min: 21-maks: 44) y11, \%65'inin kadın, $\% 56.7$ 'sinin bekar, \%65'inin lisans ve üstü mezun, $\% 81.7$ 'sinin gelirinin ortalama düzeyde, \%85'inin servis hemşiresi, \%80'ninin vardiya sistemi ile çalıştığ 1 , toplam çalışma süresi ortalamasının $7.56 \pm 6.54$ (min:1-maks:24) yıl ve haftalık çalışma saati ortalamasinın $45.35 \pm 4.03 \quad$ (min:40-maks:52) saat olduğu saptandı (Tablo 1).

Tablo 2'de görüldüğü gibi araştırmaya katılan hemşirelerin \%48.3'si işinden biraz memnun, \%18.3'ü hemşireliği tekrar seçebileceğini, \%65.0'1 hizmet içi eğitim programına ve \%48.3'ü kurum dışı seminer programlarına katıldığını, \%65.0’1 meslekle ilgili bilgileri dergi/internet/gazeteden takip ettiğini ve $\% 40$ ' 1 mesleği ile ilgili kongrelere katıldığını belirtti. Araştırma grubunun \%85.0'1 meslek dış1 sorunların, \%15.0'ı sağlık sorunlarının, \%20.0'1 iş arkadaşlarının, $\% 51.7$ 'si kurum içi politikaların ve \%15.0'1 ailevi sorunların meslek yaşamını etkilediğini ifade etti.

Tablo 3'te araştırma grubunun ÖSÖ, ÇYKÖ ve BDÖ24'den aldıkları puanlar gösterildi. Hemşirelerin ÖSÖ toplam puan ortalaması $34.55 \pm 6.71$, bilişsel, duyuşsal ve davranışsal alt boyut puanları sırası ile 13.62 \pm 3.41 , $9.15 \pm 2.28$ ve $11.78 \pm 2.63$ 'dır. Çalışma Yaşam Kalitesi Ölçeği alt boyut puan ortalamaları; mesleki tatmin: $27.62 \pm 6.62$, tükenmişlik $7.57 \pm 2.73$ ve eşduyum yorgunluğu 17.10 \pm 7.35 'dir. Bakım Davranışları Ölçeği-24 toplam puan ortalaması $5.20 \pm 0.45$, alt boyut puanları ise güvence: $5.13 \pm 0.54$, saygilı olma: $5.17 \pm 0.50$, bilgi beceri: $5.36 \pm 0.52$ ve bağlilik: $5.21 \pm 0.58$ olarak saptand1.

Cerrahi birimlerde çalışan hemşirelerin ÖSÖ toplam puanı ile iş memnuniyeti $(z=-5.175, p<0.001)$ ve meslek dışı sorunların meslek yaşamına etkisi ( $\mathrm{z}=$ 2.006, $\mathrm{p}=0.045)$ arasında istatistiksel olarak anlamlı fark saptandi. 
Tablo 1. Araştırma Grubunu Oluşturan Hemşirelerin Tanıtıcı Özelliklerine Göre Dağılımı (n=60)

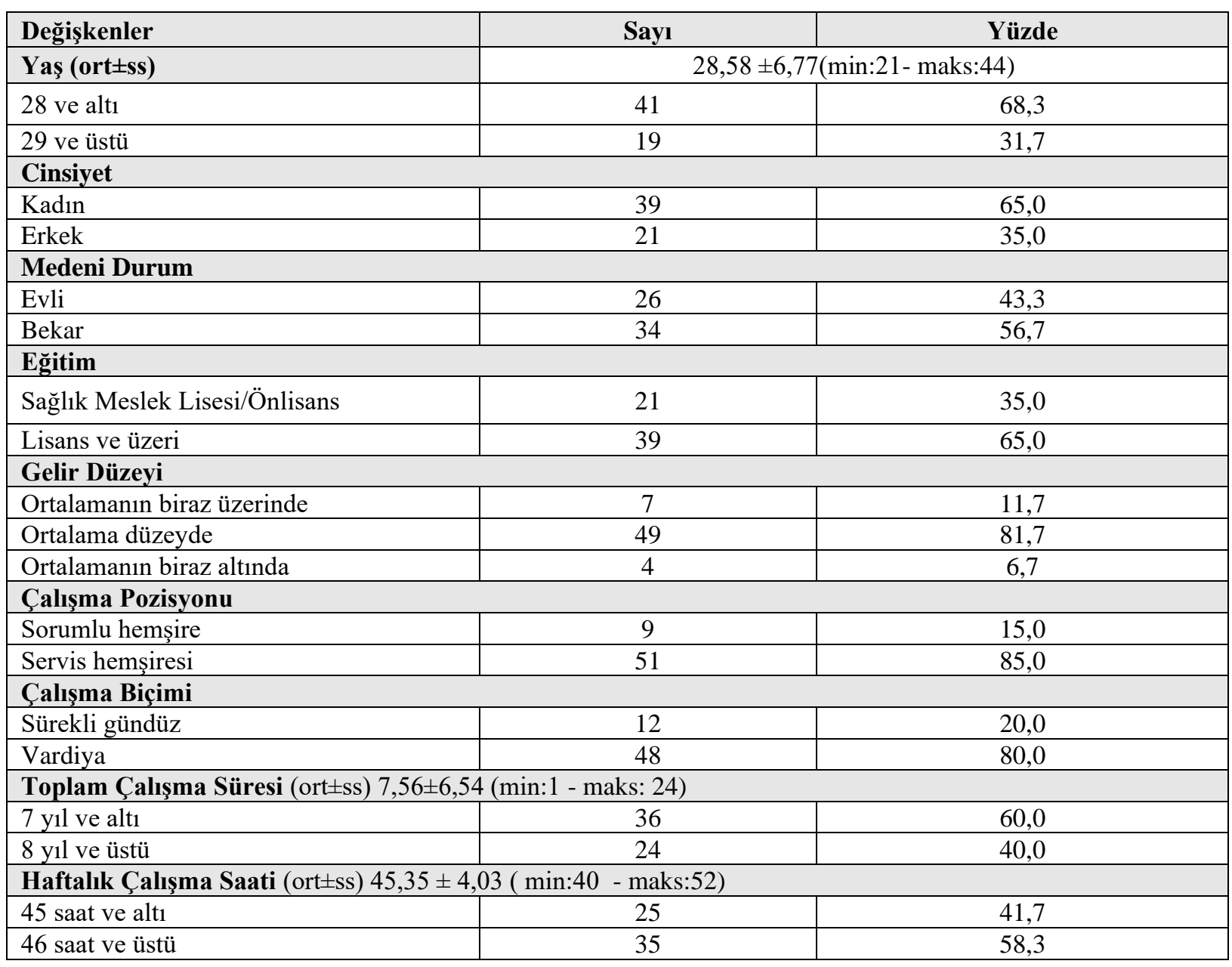

Ort: Aritmatik ortalama, ss: standart sapma, min: en küçük değer, maks: en büyük değer

İşinden biraz memnun ve meslek dişı sorunların meslek yaşamını etkilediğini belirtenlerin puanları daha yüksektir. Çalışanlar için Yaşam Kalitesi Ölçeği alt boyutlarından mesleki tatminin yaş, işten memnuniyet, hizmet içi eğitime katılma durumu ve kurum içi politikaların meslek yaşamını etkileme durumu arasında istatistiksel olarak anlamlı fark bulundu $(\mathrm{p}<0.05)$. Yirmi dokuz yaş ve üzerindekilerin, işinden memnun olan, hizmet içi eğitime katılan ve kurum içi politikaların meslek yaşamını etkilemeyenlerin mesleki tatmin puanları daha yüksektir. Tükenmişlik ile çalışma biçimi, kurum içi politikaların ve meslek dışı sorunların meslek yaşamına etkisi arasında istatistiksel olarak anlamlı fark belirlendi $(\mathrm{p}<0.05)$. Sürekli gündüz çalışan, meslek dişı sorunların ve kurum içi politikaların meslek yaşamını etkileyenlerin tükenmişlik puanları daha yüksektir. Eşduyum yorgunluğu ile iş memnuniyeti, hizmet içi eğitime katılma durumu, meslek dişı sorunların ve kurum içi politikaların meslek yaşamına etkisi arasında istatistiksel olarak anlamlı fark saptand $1(\mathrm{p}<0.05)$. İşten daha az memnun olanların, hizmet içi eğitime katılanların, meslek dışı sorunların ve kurum içi politikaların meslek yaşamını etkileyenlerin eşduyum yorgunluğu puanları daha yüksektir. Bakım davranışları Ölçeği-24 toplam puanı ile yaş, cinsiyet, çalışma biçimi, çalışma süresi, işten memnuniyet ve hizmet içi eğitime katılma durumu arasında istatistiksel olarak anlamlı fark belirlendi $(\mathrm{p}<0.05)$. Yaşı 28 ve altındakilerin, erkeklerin, yedi yıl ve altı süredir çalışanların, vardiya usulü çalışanların, işinden biraz memnun olanların ve hizmet içi eğitime katılmayanların puanları daha yüksektir (Tablo 4).

Örgütsel Sinizm Ölçeği toplam puanı ile ÇYKÖ alt boyutlarından mesleki tatmin arasında negatif yönlü orta $\left(\mathrm{r}_{\mathrm{s}}=-0.456, \mathrm{p}<0.001\right)$, tükenmişlik arasında pozitif yönlü zayıf, $\left(r_{s=}=0.277, p=0.032\right)$, eşduyum yorgunluğu arasında pozitif yönlü orta $\left(r_{s=} 0.372, p=0.003\right)$ ilişki saptandi (Tablo 5).

Çalışanlar için Yaşam Kalitesi Ölçeği alt boyutlarından mesleki tatmin ile BDÖ-24 toplam puanı arasında

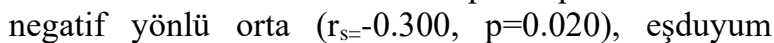
yorgunluğu ile BDÖ-24 toplam puan arasında pozitif yönlü orta $\left(r_{s}=0.603, p<0.001\right)$ düzey ilişki belirlendi (Tablo 5). 
Tablo 2. Araştırma Grubunu Oluşturan Hemşirelerin İş Memnuniyeti ve Kişisel Gelişimlerine İlişskin Düşüncelerine Göre Dağılımı

\begin{tabular}{|c|c|c|}
\hline Değişkenler & Sayı & Yüzde \\
\hline \multicolumn{3}{|l|}{ İşten Memnuniyet } \\
\hline Biraz memnun & 29 & 48,3 \\
\hline Çoğunlukla memnun & 31 & 51,7 \\
\hline \multicolumn{3}{|c|}{ Hemşireliği Tekrar Seçme Durumu } \\
\hline Evet & 11 & 18,3 \\
\hline Hayır & 18 & 30,0 \\
\hline Bilmiyor & 31 & 51,7 \\
\hline \multicolumn{3}{|c|}{ Hizmet içi Eğitime Katılma Durumu } \\
\hline Evet & 39 & 65,0 \\
\hline Hayır & 21 & 35,0 \\
\hline \multicolumn{3}{|c|}{ Kurum Dışı Seminere Katılma Durumu } \\
\hline Evet & 29 & 48,3 \\
\hline Hayır & 31 & 51,7 \\
\hline \multicolumn{3}{|c|}{ Meslekle İlgili Dergi/İnternet/Gazete Takip Etme Durumu } \\
\hline Evet & 39 & 65,0 \\
\hline Hayır & 21 & 35,0 \\
\hline \multicolumn{3}{|c|}{ Kongreye Gitme Durumu } \\
\hline Evet & 24 & 40,0 \\
\hline Hayır & 36 & 60,0 \\
\hline \multicolumn{3}{|c|}{ Meslek Dışı Sorunların Meslek Yaşamına Etkisi } \\
\hline Evet & 51 & 85,0 \\
\hline Hayır & 9 & 15,0 \\
\hline \multicolumn{3}{|c|}{ Sağlık Sorunlarının Meslek Yaşamına Etkisi } \\
\hline Evet & 9 & 15,0 \\
\hline Hayır & 51 & 85,0 \\
\hline \multicolumn{3}{|c|}{ İş Arkadaşlarının Meslek Yaşamına Etkisi } \\
\hline Evet & 12 & 20,0 \\
\hline Hayır & 48 & 80,0 \\
\hline \multicolumn{3}{|c|}{ Kurum İçi Politikaların Meslek Yaşamına Etkisi } \\
\hline Evet & 31 & 51,7 \\
\hline Hayır & 29 & 48,3 \\
\hline \multicolumn{3}{|c|}{ Ailevi Sorunların Meslek Yaşamına Etkisi } \\
\hline Evet & 9 & 15,0 \\
\hline Hayır & 51 & 85,0 \\
\hline
\end{tabular}

Tablo 3. Hemşirelerin Örgütsel Sinizm Ölçeği, Bakım Davranışları Ölçeği ve Çalışanlar için Yaşam Kalitesi Ölçeği Puanlarına Göre Dağılımı

\begin{tabular}{|l|c|c|}
\hline Ölçekler & Ort \pm ss (min-maks) & Ortanca (ÇAA) \\
\hline Örgütsel Sinizm & & $13,50(12,00-15,00)$ \\
\hline Bilişsel & $13,62 \pm 3,41(5,00-25,00)$ & $9,00(8,00-14,00)$ \\
\hline Duyuşsal & $9,15 \pm 2,28(4,00-14,00)$ & $12,00(10,00-14,00)$ \\
\hline Davranışsal & $11,78 \pm 2,63(5,00-16,00)$ & $36,00(31,00-38,00)$ \\
\hline Örgütsel Sinizm Toplam & $34,55 \pm 6,71(14,00-48,00)$ & $28,00(22,00-31,00)$ \\
\hline Çalışanlar için Yaşam Kalitesi Ölçeği & \multicolumn{2}{|l|}{} \\
\hline Mesleki Tatmin & $27,62 \pm 6,62(18,00-45,00)$ & $8,00(6,00-9,00)$ \\
\hline Tükenmişlik & $7,57 \pm 2,73(1,00-13,00)$ & $18,00(10,75-23,75)$ \\
\hline Eşduyum Yorgunluğu & $17,10 \pm 7,35(3,00-28,00)$ & $5,19(4,78-5,50)$ \\
\hline Bakım Davranışları Ölçeği-24 & $5,13 \pm 0,54(3,38-6,00)$ & $5,25(4,83-5,67)$ \\
\hline Güvence & $5,17 \pm 0,50(4,00-6,00)$ & $5,00(5,00-5,80)$ \\
\hline Saygılı Olma & $5,36 \pm 0,52(4,00-6,00)$ & $4,80(4,80-5,80)$ \\
\hline Bilgi Beceri & $5,21 \pm 0,58(3,80-6,00)$ & $5,17(4,92-5,61)$ \\
\hline Bağlilık & $5,20 \pm 0,45(4,21-6,00)$ & \\
\hline Bakım Davranışları Ölçeği Toplam &
\end{tabular}

Ort: Aritmatik ortalama, ss: standart sapma, min: en küçük değer, maks: en büyük değer,ÇAA: çeyreklerarası aralık 
Tablo 4. Değişkenler ile Örgütsel Sinizm Ölçeği, Çalışanlar için Yaşam Kalitesi Ölçeği ve Bakım Davranışları Ölçeği Puanlarının Karşılaştırılması

\begin{tabular}{|c|c|c|c|c|c|c|}
\hline \multirow[t]{2}{*}{ Değişkenler } & Sayı & ÖSÖ Toplam & $\begin{array}{c}\text { ÇYKÖ-Mesleki } \\
\text { Tatmin }\end{array}$ & $\begin{array}{c}\text { ÇYKÖ- } \\
\text { Tükenmişlik }\end{array}$ & $\begin{array}{c}\text { ÇYKÖ-Eşduyum } \\
\text { Yorgunluğu }\end{array}$ & BDÖ-24 Toplam \\
\hline & & Ortanca (ÇAA) & Ortanca (ÇAA) & Ortanca (ÇAA) & Ortanca (ÇAA) & Ortanca (ÇAA) \\
\hline \multicolumn{7}{|l|}{ Yaş } \\
\hline 28 ve altt & 41 & $36,00(29,00-37,00)$ & $25,00(21,00-31,00)$ & $8,00(5,00-9,00)$ & $19,00(9,50-25,50)$ & $5,42(5,00-5,71)$ \\
\hline 29 ve üstü & 19 & $36,00(31,00-3700)$ & $29,00(28,00-31,00)$ & $9,00(6,00-10,00)$ & $17,00(14,00-19,00)$ & $4,87(34,00-41,00)$ \\
\hline Test $\dot{I}_{\text {statistiğ } i}$ & & $\mathrm{z}=-0,861, \mathrm{p}=0,389$ & $\mathrm{z}=-2,095, \mathrm{p}=\mathbf{0 , 0 3 6}$ & $\mathrm{z}=-1,928, \mathrm{p}=0,054$ & $\mathrm{z}=-1,202, \mathrm{p}=0,229$ & $\mathrm{z}=-4,079, \mathrm{p}<\mathbf{0 , 0 0 1}$ \\
\hline \multicolumn{7}{|l|}{ Cinsiyet } \\
\hline Erkek & 21 & $36,00(32,00-39,00)$ & $27,00(21,00-32,50)$ & $9,00(6,50-9,00)$ & $19,00(13,00-23,50)$ & $5,42(5,06-5,75)$ \\
\hline Kadın & 39 & $35,00(31,00-38,00)$ & $28,00(22,00-31,00)$ & $8,00(6,00-10,00)$ & $17,00(8,00-24,00)$ & $5,00(4,87-5,54)$ \\
\hline Test İstatistiğ & & $\mathrm{z}=-0,646, \mathrm{p}=0,518$ & $\mathrm{z}=-0,171, \mathrm{p}=0,864$ & $\mathrm{z}=-0,439, \mathrm{p}=0,661$ & $\mathrm{z}=-0,396, \mathrm{p}=0,692$ & $\mathrm{z}=-2,164, \mathbf{p}=\mathbf{0 , 0 3 0}$ \\
\hline \multicolumn{7}{|l|}{ Çalş̧ma Süresi } \\
\hline 7 yil ve altı & 36 & $36,00(31,00-37,75$ & $25,50(21,00-31,00)$ & $8,00(5,25-9,00$ & $17,50(9,25-24,75)$ & $5,42(5,00-5,70)$ \\
\hline 8 yll ve üstü & 24 & $35,00(31,25-38,75)$ & $29,00(24,50-30,75)$ & $9,00(6,00-10,00)$ & $18,00(14,25-21,25)$ & $4,94(4,76-5,17)$ \\
\hline Test İstatistiği & & $\mathrm{z}=-0,371, \mathrm{p}=0,711$ & $\mathrm{z}=-1,376, \mathrm{p}=0,169$ & $\mathrm{z}=-1,167, \mathrm{p}=0,243$ & $\mathrm{z}=-0,219, \mathrm{p}=0,826$ & $\mathrm{z}=-3,035, \mathbf{p}=\mathbf{0}, \mathbf{0 0 2}$ \\
\hline \multicolumn{7}{|l|}{ Çalş̧̦ma Biçimi } \\
\hline Sürekli gündüz & 12 & $32,00(31,00-37,75)$ & $29,00(29,00-31,50)$ & $9,00(8,25-10,00)$ & $18,00(17,00-19,00)$ & $4,87(4,67-5,15)$ \\
\hline Vardiya & 48 & $36,00(31,25-38,00)$ & $26,00(21,25-31,00)$ & $8,00(5,00-9,00)$ & $17,00(9,25-25,00)$ & $5,33(4,97-5,67)$ \\
\hline Test İstatistiği & & $\mathrm{z}=-0,714, \mathrm{p}=0,475$ & $\mathrm{z}=-1,732, \mathrm{p}=0,083$ & $\mathrm{z}=-2,168, \mathrm{p}=\mathbf{0}, \mathbf{0 3 0}$ & $\mathrm{z}=-0,241, \mathrm{p}=0,810$ & $\mathrm{z}=-3,042, \mathbf{p}=\mathbf{0 , 0 0 2}$ \\
\hline \multicolumn{7}{|l|}{ İșten Memnuniyet } \\
\hline Biraz memnunum & 31 & $37,00(36,00-39,50)$ & $22,00(20,00-25,00)$ & $9,00(7,00-9,50)$ & $24,00(16,00-27,00)$ & $5,54(5,10-5,69)$ \\
\hline $\begin{array}{l}\text { Çoğunlukla } \\
\text { memnun }\end{array}$ & 29 & $31,00(29,00-34,00)$ & $30,00(29,00-33,00)$ & $7,00(4,00-9,00)$ & $15,00(8,00-18,00)$ & $5,00(4,79-5,29)$ \\
\hline Test İstatistiğ i & & $\mathrm{z}=-5,17, \mathrm{p}<\mathbf{0 , 0 0 1}$ & $\mathrm{z}=-5,612, \mathrm{p}<\mathbf{0 , 0 0 1}$ & $\mathrm{z}=-1,585, \mathrm{p}=0,113$ & $\mathrm{z}=-3,854, \mathrm{p}<\mathbf{0 , 0 0 1}$ & $\mathrm{z}=-3,079, \mathbf{p}=\mathbf{0 , 0 0 2}$ \\
\hline \multicolumn{7}{|c|}{ Hizmet içi Eğitime Katılma Durumu } \\
\hline Evet & 39 & $35,00(31,00-38,00)$ & $28,00(22,00-30,00)$ & $9,00(6,00-9,00)$ & $17,00(13,00-22,00)$ & $5,08(4,79-5,42)$ \\
\hline Hayır & 21 & $36,00(31,50-38,00)$ & $27,00(21,50-33,00)$ & $8,00(4,50-9,50)$ & $19,00(8,50-24,50)$ & $5,54(5,00-5,73)$ \\
\hline Test İstatistiği & & $\mathrm{z}=-0,626, \mathrm{p}=0,531$ & $\mathrm{z}=-3,261, \mathrm{p}=\mathbf{0}, \mathbf{0 0 1}$ & $\mathrm{z}=-1,053, \mathrm{p}=0,292$ & $\mathrm{z}=-3,054, \mathrm{p}=\mathbf{0}, \mathbf{0 0 2}$ & $\mathrm{z}=-2,334, \mathrm{p}=\mathbf{0}, \mathbf{0 2 0}$ \\
\hline \multicolumn{7}{|c|}{ Meslek Dıșı Sorunların Meslek Yaşamına Etkisi } \\
\hline Evet & 51 & $36,00(32,00-38,00)$ & $27,00(22,00-32,00)$ & $9,00(6,00-10,00)$ & $18,00(14,00-25,00)$ & $5,25(4,92-5,62)$ \\
\hline Hayır & 9 & $32,00(29,00-34,50)$ & $29,00(24,00-30,50)$ & $6,00(3,50-8,50)$ & $8,00(7,00-15,00)$ & $4,96(4,81-5,10$ \\
\hline Test İstatistiği & & $\mathrm{z}=-2,006, \mathrm{p}=\mathbf{0 , 0 4 5}$ & $\mathrm{z}=-0,052, \mathrm{p}=0,959$ & $\mathrm{z}=-2,114, \mathrm{p}=\mathbf{0}, \mathbf{0 3 4}$ & $z=-2,894, p=0,004$ & $\mathrm{z}=-1,492, \mathrm{p}=0,136$ \\
\hline \multicolumn{7}{|c|}{ Kurum İçi Politikaların Meslek Yaşamına Etkisi } \\
\hline Evet & 31 & $37,00(34,00-38,00)$ & $23,00(20,00-29,00)$ & $9,00(8,00-10,00)$ & $23,00(18,00-27,00)$ & $5,50(4,87-5,67)$ \\
\hline Hayır & 29 & $32,00(29,00-38,00)$ & $31,00(27,50-33,00)$ & $7,00(4,00-9,00)$ & $13,00(7,00-17,00)$ & $5,00(4,92-5,40$ \\
\hline Test İstatistiği & & $\mathrm{z}=-1,930, \mathrm{p}=0,054$ & $\mathrm{z}=-4,448, \mathrm{p}<\mathbf{0 , 0 0 1}$ & $\mathrm{z}=-3,186, \mathrm{p}=\mathbf{0 , 0 0 1}$ & $\mathrm{z}=-4,965, \mathrm{p}<\mathbf{0 , 0 0 1}$ & $\mathrm{z}=-1,466, \mathrm{p}=0,143$ \\
\hline
\end{tabular}

ÖSÖ: Örgütsel Sinizm Ölçeği, ÇYKÖ: Çalışanlar için Yaşam Kalitesi Ölçeği, BDÖ: Bakım Davranışları Ölçeği, z:Mann Whitney U testi, ÇAA: çeyreklerarası aralı

\subsection{Tartısma}

Araştırmaya katılan hemşirelerin yaş ortalaması 28.58 \pm 6.77 yıl, çoğunluğunun kadın, bekar ve lisans/lisansüstü mezun, toplam çalışma süresi ortalaması $7.56 \pm 6.54$ yıl, haftalık çalışma saati ortalaması $45.35 \pm 4.03$ saat olarak saptanmıştır. Araştırmaya katılan hemşirelerin yaşlarının genç olması, katılımcılarında doğal olarak büyük çoğunluğunun bekar ve toplam çalışma sürelerinin yedi yıldan daha az olmasının nedenini ortaya koymaktadır. Ülkemizde hemşirelerde örgütsel sinizm ile ilgili yapılan çalışmalarda da araştırma grubunun genç ve lisans/ lisansüstü eğitim düzeyine sahip hemşirelerden oluştuğu belirtilmiştir [23, 24]. Araştırma bulguları literatür ile uyum göstermektedir. Hemşireler yaptıkları işten biraz memnun olduklarını (\%48.3) ve kurum içi politikaların meslek hayatlarını etkilediğini (\%51.7) bildirmişlerdir. Günüşen ve Üstün'ün 2010 yılında yaptıkları çalışmada da kurumsal değişsenlerin, uzun çalışma saatlerinin ve çalışılan ortamdan duyulan memnuniyetsizliğin hemşirelerin tükenmiş̧lik düzeylerine etki edebileceği gösterilmiştir [25]. Yapılan benzer çalışmalarda da kurum yöneticilerinin çalışanlardan daha çok kendi ihtiyaçlarını göz önünde bulunduran politikalar izlediklerinde hemşirelerin kendilerini yıpranmış hissederek hizmet verdikleri kişilere kayıtsız davrandıkları ve yaptıkları iş ile 
Tablo 5. Hemşirelerin Örgütsel Sinizm Ölçeği, Çalışanlar için Yaşam Kalitesi Ölçeği ve Bakım Davranışları Ölçeği24 Puanları Arasındaki İlişki

\begin{tabular}{|c|c|c|c|c|c|}
\hline 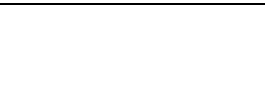 & $\begin{array}{l}\text { Örgütsel Sinizm } \\
\text { Ölçeği Toplam }\end{array}$ & $\begin{array}{l}\text { CYKÖ } \\
\text { Mesleki Tatmin }\end{array}$ & $\begin{array}{l}\text { CYKKÖ } \\
\text { Tükenmişlik }\end{array}$ & $\begin{array}{l}\text { ÇYKÖ } \\
\text { Eşduyum } \\
\text { Yorgunluğu }\end{array}$ & $\begin{array}{l}\text { Bakım Davranışları } \\
\text { Ölçeği-24 Toplam }\end{array}$ \\
\hline $\begin{array}{l}\text { Örgütsel Sinizm } \\
\text { Ölçeği Toplam }\end{array}$ & 1,00 & $\begin{array}{l}\mathbf{r}_{\mathrm{s}=-\mathbf{0}, \mathbf{4 5 6}} * * \\
\mathrm{p}<0,001\end{array}$ & $\begin{array}{l}\mathbf{r}_{\mathrm{s}}=\mathbf{0 , 2 7 7} * \\
\mathrm{p}=0,032\end{array}$ & $\begin{array}{l}\mathbf{r}_{\mathrm{s}=} \mathbf{0 , 3 7 2} * * \\
\mathrm{p}_{\mathrm{p}}=0,003\end{array}$ & $\begin{array}{l}\mathbf{r}_{\mathrm{s}}=0,252 \\
\mathrm{p}=0,052\end{array}$ \\
\hline Mesleki Tatmin & & 1,00 & $\begin{array}{l}\mathbf{r}_{\mathrm{s}=}=\mathbf{- 0 , 2 9 7} * 0, \\
\mathrm{p}=0,021\end{array}$ & $\begin{array}{l}\mathbf{r}_{\mathrm{s}=}=\mathbf{- 0 , 6 5 5} * * \\
\mathrm{p}<0,001\end{array}$ & $\begin{array}{l}\mathbf{r}_{\mathrm{s}}=-0,300^{*} \\
\mathrm{p}=0,020\end{array}$ \\
\hline Tükenmişlik & & & 1,00 & $\begin{array}{l}\mathbf{r}_{\mathrm{s}=} \mathbf{0}, \mathbf{4 4 2} * * \\
\mathrm{p}<0,001\end{array}$ & $\begin{array}{l}\mathbf{r}_{\mathrm{s}}=0,025 \\
\mathrm{p}=0,849\end{array}$ \\
\hline $\begin{array}{l}\text { Eşduyum } \\
\text { Yorgunluğu }\end{array}$ & & & & 1,00 & $\begin{array}{l}\mathbf{r}_{\mathrm{s}=0,603 * *} * 0, \\
\mathrm{p}<0,001\end{array}$ \\
\hline $\begin{array}{l}\text { Bakım } \\
\text { Davranışları } \\
\text { Ölçeği-24 } \\
\text { Toplam }\end{array}$ & & & & & 1,00 \\
\hline
\end{tabular}

$\mathrm{r}_{\mathrm{s}:}$ Spearman's rho ${ }^{* *} \mathrm{p}<0.01,{ }^{*} \mathrm{p}<0.05$, ÇYKÖ: Çalışanlar için Yaşam Kalitesi Ölçeği

ilgili performanslarının daha düşük olduğu saptanmıştır $[26,27]$. Hemşirelerin çalışma saati, nöbet düzeni gibi meslek yaşamına yönelik oluşturulan kurum içi politikaların çalışma yaşamına ve yapılan işten duyulan memnuniyete etkisi olduğu düşünülmektedir.

Araştırmada hemşirelerin işten memnuniyet düzeyleri ile ÖSÖ toplam puanı arasında anlamlı fark olduğu bulunmuştur. Örgütsel sinizmin işten ayrılma niyeti ile ilişkisinin incelendiği bir çalışmada işten ayrılan hemşirelerde örgütsel sinizm düzeylerinin daha düşük olduğu, aynı işe devam edenlerde ise örgütsel sinizm düzeylerinin daha yüksek olduğu belirlenmiştir [28]. Benzer şekilde hemşireler ve hekimler ile yapılan başka bir çalışmada da örgütsel sinizmin ișten duyulan tatmin üzerine olumsuz bir etkisi olduğu saptanmıştır [29]. Hemşirelerin yoğun çalışma koşullarının iş memnuniyetleri üzerine olumsuz etki edebileceği göz önünde bulundurulduğunda örgütsel sinizm iş memnuniyetini olumsuz yönde etkilemiş olabilir.

Araştırmada BDÖ-24 toplam puanı ile yaş, cinsiyet, çalışma biçimi, çalışma süresi, işten memnuniyet ve hizmet içi eğitime katılma durumu arasında istatistiksel olarak anlamlı fark belirlenmiştir. Hemşirelik bakım davranışlarının etkili düzeyde olması sağlık politikaları, kurum içi örgütsel işleyiş, sağlığa ayrılan kaynaklar gibi çeşitli faktörlerden etkilenmektedir [30]. Araştırma bulgularına paralel olarak iş tatmini, iş yoğunluğu ve hasta sayısının fazla olmasının hemşirelik bakımını olumsuz yönde etkilediğini gösteren çeşitli çalışmalar literatürde bulunmaktadır [31-33]. Hemşirelerin vardiya sisteminde çalışması, kurum içi politikaların meslek hayatlarına etkisi hemşirelerin iş memnuniyeti düzeylerini etkileyebileceği ve bu durumunda bakım davranışlarına yansıyabileceği düşünülebilir.

Araştırmaya katılan hemşirelerin ÇYKÖ alt boyutlarından mesleki tatmin ile yaş, işten memnuniyet, hizmet içi eğitime katılma durumu ve kurum içi politikalarının meslek yaşamına etkisi arasında anlamlı bir ilişki bulunmuştur. Sivas'ta bir devlet hastanesinde çalışan hemşireler ile yapılan çalışmada hemşirelerin mesleki tatmin düzeylerinin düşük olduğu belirlenmiştir [34]. Farklı olarak yapılan bir çalışmada çalışılan birimin mesleki tatmini etkilediği ve yoğun bakımda çalışan hemşirelerin mesleki tatmin düzeylerinin daha yüksek olarak bildirilmiștir [35]. Yapılan başka bir çalışmada ise hemşirelerin mesleklerinden memnun oldukları ve tatmin düzeylerinin yüksek olduğu saptanmıştır [36]. Hemşirelerde mesleki tatmine ilişkin yapılan çalışmalarda da görüldüğü gibi farklı sonuçlar mevcuttur. Hemşirelerin yaptıkları işten memnuniyetleri, çalışma koşulları ve hatta çalıştıkları birimler mesleki tatmin düzeylerinde farklılık görülmesine neden olabilmektedir.

Araştırmaya katılan hemşirelerin ÇYKÖ alt boyutlarından tükenmişlik ile çalışma biçimi, meslek dışı sorunların meslek yaşamına etkisi ve kurum içi politikaların meslek yaşamına etkisi arasında anlamlı fark saptanmıştır. Yapılan bir çalışmada hemşirelerin çalışma süreleri arttıkça tükenmişlik düzeylerinin de arttığ1 saptanmıştır [37]. Hemşirelerin tükenmişlik seviyelerinin incelendiği çeşitli çalışmalarda tükenmişlik düzeylerinin genel olarak yüksek ya da diğer çalışmalara benzer olduğu bulunmuştur [38-41]. Uzun süre çalışmaya bağlı oluşan yorgunluğun hemşirelerin çalışma yaşam kalitelerini olumsuz etkilediği belirlenmiştir [42]. Bu konu ile ilgili yapılan çalışmalardan da görüldüğü üzere genel olarak uzun çalışma süreleri ile ilgili kurum politikaları, çalışma biçimi ve bunlara bağlı meydana gelen yorgunluk hemşirelerin tükenmiş hissetmelerine neden olabilir. Araştırmaya katılan hemşirelerin ÇYKÖ alt boyutlarından eşduyum yorgunluğu ile işten 
memnuniyet, hizmet içi eğitime katılma durumu, meslek dışı sorunların meslek yaşamına etkisi ve kurum içi politikalarının meslek yaşamına etkisi arasında anlamlı bir fark olduğu belirlenmiştir $(p<0.05)$. Hemşirelerde çalışma süresi arttıkça eş doyum yorgunluğunun arttığ bulunmuştur [37]. Literatürde hemşirelerin nöbet sistemi ile çalışmalarının eşdoyum yorgunluğuna sebep olduğu saptanmıştır [43, 44]. Uzun saatler çalışmak zorunda olan hemşirelerin kurum politikaları ile beraber çalışma koşullarının iyileştirilmesi sonucunda eşduyum yorgunluğunun daha az görülebileceği düşünülebilir.

Araştırmada ÖSÖ puanı arttıkça hemşirelerin mesleki tatmin düzeyleri azalmakta, tükenmişlik ve eşduyum yorgunlukları ise artmaktadır. Kurum yöneticileri çalışanları yerine kendi çıkarlarını ve kişisel menfaatlerini daha fazla önemsediklerinde, bu kurumda çalışan bireyler de kurum içi ilişkilerin kişisel çıkarlara bağl1 olduğunu düşünür ve geleceğe yönelik umutsuz düşünceler sergileyen bir örgüt kültüründe çalışmak zorunda hissederler. Böyle bir ortamda çalışan bireylerin kendilerini daha fazla tükenmiş ve yorgun hissettikleri, mesleklerine yönelik performans ve yeterliliklerinin ise çoğunlukla azaldığı bilinmektedir [26, 27]. Konu ile ilgili yapılan benzer bir çalışmada da öğretim üyelerinin örgütsel sinizm düzeyleri arttıkça tükenmişlik düzeylerinin de doğru oranda arttığı saptanmıştır [45]. Araştırma bulguları literatür ile benzerlik göstermektedir. Hemşirelerin kurum içerisinde yaşadığı çatışmalar, üstleri ya da çalışma arkadaşları arasındaki uyumsuzlukların mesleki tatminlerini azaltırken, tükenmişlik ve yorgunluk düzeylerini arttırabileceği görülmektedir.

\section{Sinırlılıklar}

Araştırma bir üniversite hastanesinin cerrahi birimlerinde çalışan hemşireler ile yürütüldü. Bundan dolayı çalışma sonuçları sadece bu birimlerde çalışan hemşireler için genellenebilir. Araştırmanın en önemli sınırlılığ örneklem sayısının az olmasıdır. Araştırmaya çalışmanın yapıldığ 1 ildeki iki devlet hastanesinde çalışan hemşirelerde dahil edilmek istendi. Ancak İl Sağlık Müdürlüğü tarafından kurum izni alınamadı. O nedenle sadece bir kurumda yapılabildi. Diğer bir sinırlılık verilerin yüz yüze görüşme yöntemi ile toplanmış olmasıdır. Verilerin güvenilirliği hemşirelerin verdikleri cevaplar ile sınırlıdır. Araştırmada gözleme dayalı bulguların olmaması da diğer bir sınırlılıktır. Tüm bu sınırlılıklara karşın araştırma örgütsel sinizm, çalışma yaşam kalitesi ve bakım davranışlarını birlikte değerlendirdiğinden çalışma bulgularının daha sonra yapılacak araştırmalara katkı sağlayabileceği düşünülmektedir.

\section{Sonuc}

Araştırma sonucunda; örgütsel sinizme maruz kalan cerrahi alanlarda çalışan hemşirelerin meslekle ilgili memnuniyet ve tatmin düzeylerinin olumsuz yönde etkilendiği, tükenmişlik ve eşduyum yorgunluklarının da arttığı saptandı. Ayrıca meslekte yeni ve daha genç olan hemşirelerin bakım davranışlarının daha yüksek olduğu bulundu.
Hemşirelerin hastaya uyguladığı bakımın kalitesi hastanın daha kısa sürede iyileşmesi ve taburcu olabilmesi için önemlidir. Çalışma ortamında örgütsel sinizmin oluşmasının engellenmesi, hemşireler ile çalışma koşulları açısından periyodik görüşmelerin yapılmas1 ve örgütsel sinizmin neden olabileceği olumsuz koşulların ortadan kaldırılması gereklidir. Uzun ve yorucu çalışma saatlerinin düzenlenerek mesleki tatminin arttırılıp tükenmişlik ve eşduyum yorgunluğunun azaltılması, hemşirelerin bakım davranışları ile iş memnuniyetlerinin arttırılmasına yönelik çalışma programlarının planlanması ve araştırmanın daha büyük bir örneklem grubu ile tekrarlanması önerilmektedir.

\section{Teșekkür ve Bilgilendirme}

Çalışmamıza katılıp destek veren cerrahi alanda çalışan tüm hemşirelere ve kurum yetkililerine çok teşekkür ederiz.

\section{Referanslar}

1. Kaya, Ş.D, Tekpınar, L, Tekin, G, İş yeri zorbalığ kurumlarında çalışan güvenliği bağlamında değerlendirilmesi, Selçuk Üniversitesi Sosyal Bilimler Enstitüsü Dergisi, 2019, 42, 1-22.

2. Işık, M, Candan, H, Kamu çalışanlarında örgütsel sinizmin örgütsel vatandaşlığa etkisi: Karaman ili örneği, International Journal of Economics, Politics, Humanities \& Social Sciences, 2019, 2(4), 266281.

3. Gül, H, Ağıröz, A, Mobbing ve örgütsel sinizm arasındaki ilişkiler: hemşireler üzerine bir uygulama, Afyon Kocatepe Üniversitesi IIIBF Dergisi, 2011, 13(2), 27-47.

4. Çakııı, A, Doğan, S, Örgütsel sinizmin iş performansına etkisi: meslek yüksekokullarında bir araştırma, Doğuş Üniversitesi Dergisi, 2014, 15(1), 2-5.

5. Yasin, T, Khalid, S, Organizational cynicism, work related quality of life and organizational commitment in employees, Pakistan Journal of Commerce and Social Sciences, 2015, 9(2), 568-582.

6. Koçel, T, İşletme Yöneticiliği. Beta Yayınları: İstanbul, Türkiye, 2018; s:75

7. Terzi, A.R, Derin, R, Relation between democratic leadership and organizational cynicis, Journal of Education and Learning, 2016 , 5(3), 193-204.

8. Erdoğan, $\mathrm{P}$, Bedük, A, Örgütsel sinizm ile örgütsel vatandaşlık davranışı arasındaki ilişki: Ssağlık sektöründe bir araştırma, Sosyoteknik Sosyal ve Teknik Araștırmalar Dergisi, 2013, 3(6), 1736.

9. Özler, E, Örgütsel Davranışta Güncel Konular. Ekin Basım Yayın Dağıtım: İstanbul, Türkiye, 2015; s:50-55

10. Tayfun, A, Çatır, O, Hemşirelerin örgütsel sinizm düzeylerinin incelenmesi, İsletme Araştırmaları Dergisi, 2014, 6(1), 347-365.

11. Yıldız, K, Örgütsel bağlılık ile örgütsel sinizm ve örgütsel muhalefet arasındaki ilişki, Turkish Studies International Periodical For The Languages, Literature and History of Turkish or Turkic, 2013, 8(6), 853-879.

12. Güner, E, Yıldırım, M.H, İçerli, L, Hizmet işletmelerinde çalıșanların örgütsel güven ve sinisizm davranışı arasındaki ilişki, Organizasyon ve Yönetim Bilimleri Dergisi, 2012, 4(1), 76.

13. Baz, M, Kaya, S, Savaș, K, İșveren ve iş gören ilișkileri, Uluslararas Hakemli Akademik Sosyal Bilimler Dergisi, 2011, 1(1), 91-92.

14. Özler, D.E, Atalay, C.G, A research to determine the relationship between organizational cynicism and burnout levels of employees in health sector, Business and Management Review, 2011, 1(4), 26-38.

15. Bilazer, F.N, Konca, G.E, Uğur, S, ve ark, Türkiye'de Hemșirelerin Çalışma Koşulları. Türk Hemşireler Derneği Yayınları, Odak Ofset Matbaacılık: Ankara,Türkiye, 2008; 22-37.

16. Barutçu, E, Serinkan, C, Günümüzün önemli sorunlarından biri olarak tükenmişlik sendromu ve Denizli'de yapılan bir araştırma, Ege Akademik Bakıs, 2008, 8(2), 541-561.

17. Ergin, D, Celasin, N, Akış, Ş, ve ark, Dahili kliniklerde görev yapan hemşirelerin tükenme ve empatik beceri düzeyleri ve bunları 
etkileyen faktörlerin belirlenmesi, Fırat Sağllk Hizmetleri Dergisi, 2009, 4(11), 49-64.

18. Brandes, P.M, Organizational Cynicism: Its nature, antecedents, and consequences (dissertation of doctor of philosophy), The University of Cincinnati, 1997, 100.

19. Güzeller, C.O, Kalağan, G, Örgütsel Sinizm Ölçeğinin Türkçe’ye uyarlanması ve çeşitli değişkenler açısından eğitim örgütlerinde incelenmesi, 16.Yönetim ve Organizasyon Kongresi Kongre Kitab1: Antalya, Türkiye, 2008; 87-94.

20. Yeşil, A, Ergün, Ü, Amasyalı, C, ve ark, Çalışanlar için Yaşam Kalitesi Ölçeği Türkçe uyarlaması geçerlik ve güvenilirlik çalışması, Nöropsikiyatri Arşivi, 2010, 47(2), 111-117.

21. Wu, Y, Larrabbe, J, Putman, H, Caring behaviors inventory. Nursing Research, 2006, 55(1), 18-25.

22. Kurşun, Ş, Kanan, N. Bakım davranışları ölçeği-24'ün türkçe formunun geçerlilik ve güvenirlik çalıșması, Anadolu Hemşirelik ve Sağlık Bilimleri Dergisi, 2012, 15(4), 229-235.

23. Özer, Z. Şener, Z.T. Önav, A.K, ve ark, Dâhili kliniklerde çalışan hemşirelerin örgütsel sinizm ve tükenmişlik düzeylerinin belirlenmesi. Çekmece İzü Sosyal Bilimler Dergisi, 2018, 6(12),135 $-154$

24. Biçici, Y, Nehir, S, Hemşirelerde örgütsel sinizmin örgütsel bağlılık üzerine etkisi, Sağllk ve Hemşirelik Yönetimi Dergisi, 2020,7(2), 177 186

25. Günüşen, N, Üstün, B, Türkiye'de ikinci basamak sağlık hizmetlerinde çalıșan hemşire ve hekimlerde tükenmişlik: literatür incelemesi, Dokuz Eylül Üniversitesi Hemşirelik Yüksekokulu Elektronik Dergisi, 2010, 3(1), 40-51.

26. Fettahlığlu, Ö.O, Günümüz işletmelerinin temel hastalığı: örgütsel sinizme yönelik algılamaların, tükenmişlik boyutları üzerine etkisi, Akademik Sosyal Arasstırmalar Dergisi, 2015, 3(13), 178-191.

27. Karcıŏlu, M.S, Naktiyok, A, Örgütsel ortamda algılanan güven düzeyinin sinizm üzerindeki rolü: Atatürk Üniversitesi idari personeli üzerinde bir araştırma, Journal of Economics \& Administrative Sciences/Afyon Kocatepe Üniversitesi İktisadl ve İdari Bilimler Fakültesi Dergisi, 2015, 17(1), 19-34.

28. Mantler, J, Godin, J, Cameron, SJ, et al., Cynicism in hospital staff nurses: The effect of intention to leave and job change over time, Journal of Nursing Management, 2015, 23(5), 577-587.

29. Volpe, R.L, Mohammed, S, Hopkins, M, et al., The negative impact of organizational cynicism on physicians and nurses, Health Care Management (Frederick), 2014, 33(4), 276-288

30. Dinç, L, Bakım kavramı ve ahlaki boyutu, Sağlık Bilimleri Fakültesi Hemşirelik Dergisi, 2010, 17(2), 74-82.

31. Yang, K.P, Huang, C.K, The effects of staff nurses' morale on patien satisfaction, The Journal of Nursing Research 2005, 13(2), 141-152.

32. Raffii, F, Hajineshad, M.O, Haghani, M.O, Nurse caring in Iran and its relationship with patient satisfaction. Australian Journal of Advanced Nursing, 2009, 26(2), 75-84.

33. Burtson, P, Stichler, J, Nursing work environment and nurse caring: relationship among motivational factors, Journal of Advanced Nursing 2010, 66(8), 1819-1831.

34. Karakuş, H, Hemşirelerin iș tatmin düzeyleri: Sivas ili örneği, Dicle Üniversitesi Sosyal Bilimler Enstitüsü Dergisi, 2011, 3(6), 15-19.

35. Yoder, E.A, Compassion fatigue in nurses, Applied Nuring Research, 2010, 23(4), 191-197.

36. Keskin, G, Yıldırım, G.Ö, Hemşirelerin kişisel değerlerinin ve iş doyumlarının incelenmesi, Ege Üniversitesi Hemsirelik Yüksek Okulu Dergisi, 2006, 22 (1), 119-133.

37. Kavlu, İ, Pınar, R, Acil servislerde çalışan hemşirelerin tükenmişlik ve iş doyumlarının yaşam kalitesine etkisi, Turkiye Klinikleri Journal Medicine Science, 2009, 29(6), 1543-1555.

38. Hyeon, Ju, K, Heejung, C, Emergency nurses' professional quality of life: compassion satisfaction, burnout, and secondary traumatic stress, Journal of Korean Academy of Nursing, 2012, 18(3), 320-328.

39. Leners, C, Sowers, R, Quinn Griffin, M.T, et al, Resilience and professional quality of life among military healthcare providers, Issues in Mental Health Nursing, 2014, 35(7), 497-502.

40. Amin, A.A, Vankar, J.R, Nimbalkar, S.M, et al, Perceived stress and professional quality of life in neonatal intensive care unit nurses in Gujarat India Indian Journal of Pediatri, 2015, 82(11), 1001-1005.

41. Kim, K, Han, Y, Kwak, Y, et al, Professional quality of life and clinical competencies among Korean nurses, Asian Nursing Research, 2015, 9(3), 200-206.
42. Circenis, K, Millere, I, Deklava, L, Measuring the professional quality of life among Latvian nurses, Social and Behavioral Sciences, 2013, $84,1625-1629$

43. Smart, D, English, A, James, J, Compassion fatigue and satisfaction: A cross sectional survey among US Healthcare workers, Nursing Health Sciences, 2014, 16(1), 3-10.

44. Başkale, H, Günüşen, N, Serçekuş, P, Bir devlet hastanesinde görev yapan hemşirelerin çalıșan yașam kalitesi düzeylerinin ve etkileyen faktörlerin incelenmesi, Pamukkale Tip Dergisi, 2016, 9(2), 125-133.

45. Gün F, Başkan G.A, Öğretim elemanlarının algılarına göre örgütsel sinizm ile tükenmișlik düzeyleri arasındaki ilişkinin incelenmesi Hacettepe University Journal of Education, 2017, 32(2),361-379.

http://edergi.cbu.edu.tr/ojs/index.php/cbusbed isimli yazarın CBU-SBED başlıklı eseri bu Creative Commons Alıntı-Gayriticari4.0 Uluslararası Lisansı ile lisanslanmıştır.

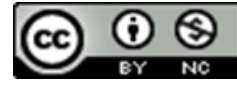

